\title{
Methodological diversity and theoretical integration: research in design fixation as an example of fixation in research design?
}

\author{
Nathan Crilly, University of Cambridge
}

(Unpublished draft, October 2019)

ABSTRACT: Over the last three decades, design fixation research has emerged as a distinct and productive area of design creativity research, and of design research more generally. In studying an applied aspect of human behaviour, fixation research is unusually restricted in its methodological choices, primarily adopting experimental and statistical approaches. The few relevant qualitative studies remain isolated from the core experimental literature. This limited diversity and limited integration restricts our ability to interpret the relevance of prior work, plan new studies and impact practice. By viewing research as a creative design activity, I argue that the fixation research community is well placed to study and change its own behaviour, and also to inform the behaviour of other research disciplines.

KEYWORDS: Design fixation, creativity, research methods, methodological pluralism, psychology of design.

Forty years ago, in the first volumes of this journal, an emerging discipline that was recognising the value of multiple approaches to designing was also recognising the value of multiple approaches to researching. This was demonstrated in several articles from the 1979 issues which explicitly discussed methodological choices. For example, Thomas and Carroll (1979) reported on various studies of design psychology based on observations, experiments and introspection. The results from their qualitative studies informed the design of subsequent experimental work, and their future research plans included further interaction between controlled laboratory studies and complex field studies (also see Carroll, Thomas, \& 
Malhotra, 1979). This engagement with the relative merits of different research approaches could also be seen in Darke's (1979) reports on interview case studies with practising architects, promoting the benefits of self-report methods over the analysis of design documents when trying to collect information about mental processes. More generally, in reviewing the options available for studying designers, Bessant (1979) listed the strengths and weaknesses of different methods, concluding that survey techniques and their associated data reduction methods had restricted previous research: "What we need now are further developments to break this 'methodological parochialism' and the notion of multiple-method study appears to offer this" (p. 78; also see Bessant \& McMahon, 1979). Clearly these authors were concerned not just with questions about what design is, how it should be practised and how it might be taught, but also with questions about how it could be studied.

Looking at design research today, the discipline as a whole demonstrates methodological diversity, with a wide range of research topics each attracting a wide range of different approaches (for an analysis, see McMahon, 2012). However, whilst the total number of topics and methods might have grown, there is less evidence of methodological comparison, argumentation or reflection. In this article I return to some of the discussions in those first issues of Design Studies, but rather than considering all of design research, I focus instead on studies of 'design fixation', a part of 'design creativity' research and a topic that happens to fit well with many of those articles from 1979. Whilst I examine design fixation research in detail, I invite readers to consider how the discussion relates to the study of other specific topics that might interest them, whether within design research or elsewhere.

In attending to issues of methodological diversity, I argue that design fixation research is largely mono-methodological, dominated by the application of techniques associated with controlled experiments. This experimental work is largely disconnected from relevant research that applies other methods, especially expert interviews and industry case studies. The direct results of this are threats to validity and relevance, and difficulty in assessing the nature and scale of those threats. Less directly, a lack of methodological diversity also limits the confidence that researchers can have in the recommendations they make for improving practice. This is a critical issue for a research topic that is often framed in terms of problems with actual design work and potential remedies to such problems.

In conducting research into design fixation, we are dependent on the application of diverse research methods to establish definitions of what it is, an accurate understanding of how it operates and reliable proposals for how it can be influenced. This is because the application of a single research method (or restricted set of methods) to a phenomenon inevitably 
distorts that phenomenon to suit the methods. Such distortion remains invisible when alternative perspectives are not available or not integrated. The risks are that we fail to develop an adequate understanding of the thing of interest or that we develop an understanding of the wrong thing altogether.

My analysis of design fixation research is framed relative to debates in other disciplines that have considered the status of their methodological commitments, the consequences of those commitments, the changes that are necessary and the challenges to making those changes. Interestingly, many of these debates about research behaviour can be seen as an analysis of the creativity and fixation exhibited by research communities. As such, researchers interested in design, creativity and fixation can apply their domain knowledge not just to understanding the subjects they study, but also to understanding how those subjects should be studied. These researchers are therefore well placed to identify and improve the behaviour of various research disciplines, including their own.

\section{Creativity and fixation}

Before we look at the methods used to research 'fixation', let's briefly consider what that term normally refers to and how it relates to 'creativity'.

When designers work on problems for which there is no obvious solution they must generate novel and appropriate ideas, thereby demonstrating creativity (Runco \& Jaeger, 2012; also see Howard, Culley, \& Dekoninck, 2008). As a contributor to product innovation, creativity is a key determinant of many organizations' commercial success and of a region's or nation's economic health (e.g. see Ekvall, 1996; Cooke, 2001). Creativity is therefore considered to be an important aspect of design performance and is the stated objective of much design education (Cropley \& Cropley, 2010; Demirkan \& Afacan, 2012). These factors all promote the importance of understanding, assessing and enhancing creative design work. Such work may require the rejection of prior assumptions, including assumptions about the problem to be addressed and the solution that is required (Newell, Shaw, \& Simon, 1962; also see Dorst, in press). Such assumptions are commonly taken to originate in the designers' prior experiences or in their exposure to some stimulus in the working environment. Where such experiences or exposure inadvertently restricts the designers' imagination this is called 'design fixation'.

Although there was some prior published work referring to 'design fixation', ${ }^{1}$ Jansson and Smith's article of that title, published in this journal in 1991, sparked a stream of research 
that could now be considered a sub-field in its own right, one aimed at understanding creativity by studying when and how it is compromised. Jansson and Smith (1991) drew on various theories of mental blocks in psychology when devising a way to measure fixation in a conceptual design task. They reported on three experimental studies where student participants worked on design problems such as a car-mounted bicycle rack, a measuring cup for the blind or a disposable spill-proof coffee cup. Alongside the design briefs, some of the participants were also presented with pictures of example solutions. The performance of these participants was compared to that of a control group who were not exposed to the example solutions. Jansson and Smith identified the occurrence of fixation in their experiments when it was observed that the participants exposed to the example solutions repeated key features of those solutions more often than those in the control group who were only provided with the design problem. This behaviour persisted even when participants were instructed to avoid repeating particular features of those example solutions. Because the features of the examples were intentionally problematic (i.e. they contradicted the requirements) this feature repetition was taken to be unconscious and counterproductive. Although seldom referred to, Jansson and Smith's (1991) article also reported on a fourth study with professional designers, demonstrating the occurrence of the fixation effect beyond the student participants who had participated in the first three studies.

Since the publication of Jansson and Smith's work, many similar studies have been conducted. These studies are now sufficiently numerous that dedicated literature reviews have recently been published (Alipour, Faizi, Moradi, \& Akrami, 2017; Sio, Kotovsky, \& Cagan, 2015; Vasconcelos \& Crilly, 2016). Many articles reporting on empirical or theoretical work also include detailed reviews of the experimental studies (for recent examples see Agogué, Kazakçi, Hatchuel, Le Masson, Weil, Poirel, \& Cassotti, 2014; Cheng, Mugge, \& Schoormans, 2014; Moreno, Blessing, Yang, Hernández, \& Wood, 2016; Viswanathan, Atilola, Esposito \& Linsey, 2014; Youmans \& Arciszewski, 2014). Given the availability of thorough and up-to-date reviews of the experimental work on design fixation, there is no need to review that work here. Instead, let's consider discussions of phenomena related to design fixation before 1991, discussions which frame the relevant phenomena in terms that are independent of any particular method of data collection or analysis.

Although Jansson and Smith's work brought the concept of design fixation to the attention of many researchers, fixation and closely related phenomena had long been discussed with respect to design. For example, Woodson's (1966) Introduction to Engineering Design refers to the importance of "breaking mental set" (p. 89; also see Lewis \& Samuel, 1989, p. 34) and Rittel (1971) warns that "a good solution is missed because of the fixation of the designer to a pet idea" (p. 20). Many other such passages can be found across different literatures: 
Whitfield (1975) discusses the role of creative work in industry, warning that "Habit, 'set' and expectation" restrict a designer's thought processes (p. 40); Tracz (1979) explores the psychological challenges of computer programming, complaining that the best solution to a problem might not be seen because of a "fixation to one approach" (p. 133). Discussing such matters in more detail, Lawson (1980) describes various 'traps' that designers might fall into, including "the category trap" - thinking within a category (and therefore transferring ideas over from other category examples automatically) (p. 152) and "the puzzle trap" - imagining that there are rules that cannot be deviated from (and therefore adhering to them unnecessarily) (p. 155). Even if we limit our search to this journal, several years before Jansson and Smith's article was published a related concept had been discussed by Hubka (1983) who advised that employing intuition and imagination to think of potential solutions prior to identifying existing solutions poses "less danger of mental set, or fixation" (p. 194; reprinted from his book of 1982, p. 40; also see pp. 56,68 ).

The long-held concern for how designers might become set, stuck, blinkered or blinded was typically expressed in terms of the work of practising designers, across disciplines, design stages, experience levels and problem types. However, since the publication of Jansson and Smith's study, design fixation research has primarily applied laboratory-based methods that are restricted to a narrower range of phenomena. These studies often either explicitly associate creative design with early-stage design activities or that association is implicit in the design tasks that participants are required to work on. The problem brief is often relatively open, requiring divergent thinking from the participants who are asked to explore a wide range of possible solutions to the problem. The participants are mostly students who must work individually, perhaps for an hour or less, producing annotated sketches to develop and record their work. It is these sketches that form the bulk of the data that the researchers then analyse, focusing on counting and classifying the ideas that the participants have generated rather than the processes through which those ideas were developed (for a review of such methodological factors, see Vasconcelos \& Crilly, 2016; but also see exceptions, such as Goucher-Lambert, Moss \& Cagan, 2019; Moreno, Hernández et al., 2014, Neroni \& Crilly, 2019; Youmans, 2011a; 2011b; Zhang, Xie \& Nourian, 2017).

\section{Consensus and conformity}

The widespread adoption and adaptation of Jansson and Smith's method has allowed some consensus to develop, especially around the definition of the phenomenon of interest (but for a deeper analysis see Youmans \& Arciszewski, 2014). Partially in response to this, Purcell 
and Gero (1996) had warned early on that "we as researchers need to be wary of becoming fixated on our conception of what fixation is" (p. 381). However, this risk of researchers exhibiting restricted imagination might apply not just to their fixation on an interpretation of the phenomenon of interest but also their fixation on how it should be studied. If understanding the occurrence of design fixation is seen as the research 'problem', and Jansson and Smith's method is an example 'solution' to that problem, does subsequent research exhibit repeated features of that example solution or do we see wide-ranging exploration of the problem and solution spaces? Put differently, if the corpus of design fixation research (after 1991) were collected and analysed how would it score on methodological 'originality', 'repetition', 'diversity', and other metrics used in fixation research? Going further, how might the outputs of a comparable group score, such as a group who had only read the accounts of fixation-related phenomena in design that predate Jansson and Smith's study?

Describing fixation researchers as being fixated might seem facetious, but it connects with two serious perspectives on research: (1) that research should be viewed as a creative activity, and (2) that researchers should apply their own domain knowledge to better understand how their disciplines behave. For examples of the first point we can look to Kara's (2015) review of the many ways in which creativity is evident in the development, selection and implementation of research methods, as well as activities of research analysis, reporting and dissemination (also see Dale \& Mason, 2011). For examples of the second point, we can consider how Podsakoff and Dalton (1987) explain Organisational Science's persistent conformity to certain methods by referring to their own field's 'Diffusion of Innovation' model (Rogers, 1983). Similarly, when Knudsen (2003) argues that Organisational Science should expand its methodological options, he says that "[this] position should not be seen as surprising since it is just an application of organisational learning theory [...] to the field of organisation studies itself" (p. 264).

In cases where researchers are studying creativity or design, the two points outlined above must overlap. For example, Runco (2015) argues that creativity researchers should learn from their own findings to make future creativity research more creative (a concept he terms 'meta-creativity'). Runco cites Cropley's (e.g. 2006) work as an instance of such an approach, referring to Cropley's intentional shifts in perspectives and his repeated questioning of prior assumptions. Similarly, Reich (2017) argues that design researchers should use design knowledge, methods and tools in designing their research, because such an approach improves outcomes. If fixation researchers were to be creative and apply their domain knowledge to establishing how the topic should be studied, how would this look? Perhaps minimally, it might be expected to involve questioning the research problem, 
checking for unnecessary assumptions and then exploring a wide range of possible solutions. However, the preferred research 'solution' is apparently the laboratory experiment, and the research 'problem' and any assumptions about it appear to remain largely unchallenged. This apparent persistence stands out against a background of increasing concern about the influence of cognitive biases in scientific research (Nature Editorial, 2015; Nuzzo, 2015). We might expect experts in design fixation to be especially sensitive to those issues, not just for tasks of limited scope that are currently receiving attention (such as confirmation bias in data analysis) but also for more open-ended tasks where a wide range of possible options might be considered (such as method development in research design).

It is not just design fixation research which exhibits a preference for experimental methods, but also design creativity research more generally. In response to this there have been repeated requests for an increase in methodological diversity. For example, in the inaugural issue of the International Journal of Design Creativity and Innovation, Badke-Schaub (2013) complains that "empirical research on creativity is often conceptualized as experimental research. Most of these studies are producing singular results standing alone and are hardly mirroring the complexity of the "real world."' (p. 13). In that same issue, Linsey (2013) observes that "We require approaches that can study a range of phenomena from individual cognitive mechanisms to innovation within a company. We need to be able to connect the data collected with multiple approaches ranging from highly controlled laboratory experiments to long-term observational studies" (p 29; also see Goldschmidt \& Tatsa, 2005, p. 610 ; c.f. Smith, 2013, p. 12).

These calls for methodological diversity reflect the expectation that there are many differences between how design activities occur 'in the lab' and how they occur 'in the wild' (Ball \& Christensen, 2018; Cash, Hicks, \& Culley, 2013). Might such differences also be expected in the study of design fixation? Well, for clues to answering this question we can look to Dunbar's (2001) discussion of how naturalistic settings promote the construction of creative analogies based on deep structural relations whilst laboratory studies promote the construction of analogies just based on superficial similarities. More generally, Cropley (2000) reports on the limited predictive validity of creativity tests when compared with subsequent creative attainment in real life (p. 78). Turning from invention to duplication, consider Linnebank, Kindt and de Wit's (2018) observations that habits form rather differently in laboratory tasks to how they do in the wider world, prompting the development of new theory (also see Marien, Custers, \& Aarts, 2019). With such differences in mind, there have been recent calls for studies that detail the contexts within which design fixation occurs (Crilly \& Cardoso, 2017; Linsey, Wessen, \& Ziemer, 2016, p. 6). Having such descriptions would allow a better understanding of the real settings to which the 
experimental studies relate and a better understanding of the strengths and limitations of such studies (for similar arguments in design research more generally, see Blessing \& Chakrabarti, 2009, p. 80; Cash, 2018).

\section{Field and laboratory}

Although they are not part of the core design fixation literature, there are accounts of design fixation (or similar phenomena) occurring in the 'real world' (for a review, see Crilly, 2019). For example, French (1971/1998, p. 201) describes the design of early gas turbines at RollsRoyce, focusing on arbitrary decisions which initially passed unnoticed, preventing the recognition of improved design options (p. 201). More extensively, Landis (1998, p. 214) provides a detailed and illustrated account of Ron Hickman's design of a portable workbench, including the role of convention in initially inhibiting the acceptance of new ideas (also see Hickman and Roos, 1982). Cross (2001, p. 55) provides an account of Kenneth Grange's work on a high-speed train, detailing Grange's report of how technical opportunities had been overlooked by the engineers because of precedent. More recently, Crilly \& Moroşanu Firth (2019) provide an account of Brian Meek's development of a new handsaw, documenting how the original manufacturing method slowed the recognition of a superior approach to shaping the components. These accounts and others like them typically provide some illustration of the design work progressing and report on the designers' own perspectives on why design changes were or weren't made at particular moments.

In addition to explicit accounts of fixation episodes in design projects, there are reports of practising designers reflecting on contexts and behaviours that are related to fixation. There are many examples of this in Crilly's (2015) interviews with expert design consultants. Earlier examples can be found in Roy's (1993) study of James Dyson (e.g. see p. 440), Cross and Clayburn Cross' (1996) study of Gordon Murray (e.g. see p. 98) and in Candy and Edmonds' (1996) study of Mike Burrows (e.g. see p. 77). These and similar studies report on the researchers' analyses of various contexts and behaviours relevant to fixation, based on evidence from practice. Some of these accounts make explicit reference to fixation effects, for example in the context of solution search (Busby \& Lloyd, 1999a; 1999b), adaptation of prior work (Eckert, Stacey, \& Earl, 2005), computer-based design support tools (Robertson \& Radcliffe, 2006; 2009) and inspiration storage and retrieval methods (Herring, Chang, Krantzler \& Bailey, 2009). These are just some examples, but there must be many more, spread across various literatures (for more detail, see Crilly, 2019). 
Because research approaches can be defined according to many different dimensions it is often difficult to make clear distinctions between recognisable streams of research, such as labelling some work as 'quantitative' and other work as 'qualitative' (e.g. see Morgan, Gliner, \& Harmon, 1999; Walsh, 2012). For design fixation such distinctions are fairly unproblematic though. Most of the relevant work does indeed fall into one of two categories: that which is controlled, experimental, laboratory-based and quantitative, and that which is naturalistic, field-based, context-oriented and qualitative. It might seem from the brief review above, that both of these forms of research have investigated design fixation and therefore that the subject might already benefit from good levels of methodological diversity. There are, after all, not just laboratory studies of students undertaking artificial assignments, but also accounts of design fixation occurring 'in the wild' and studies of the work activities that are relevant to such occurrences. However, there is a far greater volume of experimental work and a clear separation between that work and the qualitative work that it might relate to.

Many experimental studies make some general reference to real-world contexts and practices, especially with respect to the use of visual stimuli (e.g. with citations to Eckert \& Stacey, 2000; Henderson, 1999; Keller, Pasman, \& Stappers, 2006). However, these references are seldom part of any detailed review, and it is extremely rare for experimental studies to refer to contextual accounts where fixation-related phenomena are discussed. One notable exception is Heylighen and Verstijnen's (2003) reference (albeit in an endnote) to interviews with architects who describe fixation-related effects; they cite interviews by Heylighen and Neuckermans (2002, e.g. see p. 10) and Lawson (1994, the Venturi and Brown cases). Looking at it the other way round, the qualitative literature related to fixation makes only a few references to the experimental literature, and that is often just to establish the basic concept and cite the origin of a term or definition. It would seem that despite similar interests and objectives (whether stated or implied), these two related literatures effectively belong to different communities (see Figure 1 ). ${ }^{2}$ 


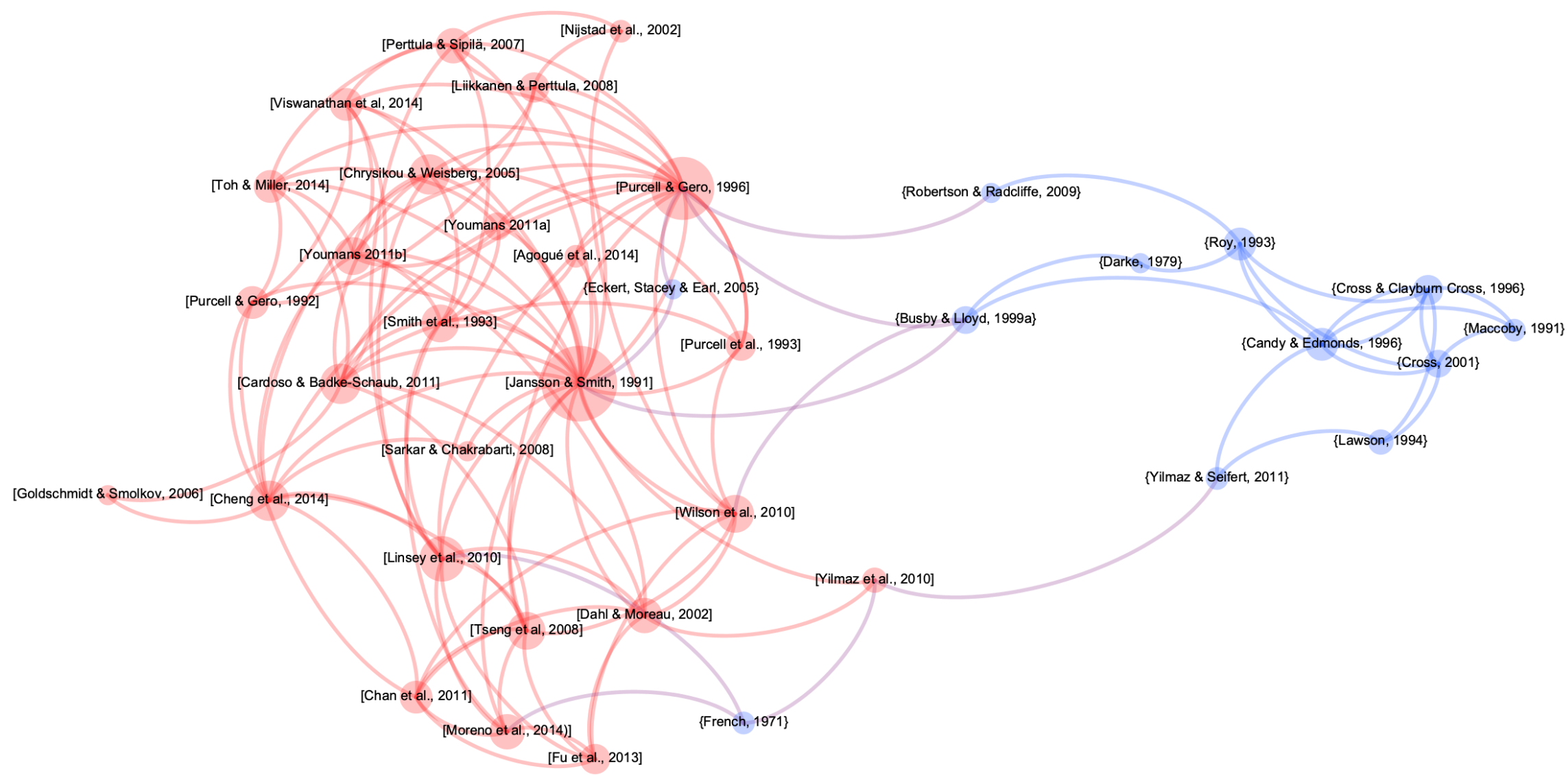

Figure 1. Citation network of publications related to design fixation (sampled from recent literature reviews by Crilly, 2005; 2019; Sio et al., 2015; Vasconcelos \& Crilly, 2016). Texts reporting experimental studies are shown as red nodes [and author-date are in square brackets], mostly clustered to the left; texts providing qualitative accounts are shown as blue nodes \{and author-date are in curly brackets\}, mostly clustered to the right. Edges (links) between nodes represent citations, with the edge colour matched to the citing text. Node size is scaled with incoming citations (from nodes within this network only). The layout of the network is force-directed so that well-connected texts are closer together than less-well-connected texts. Only texts with two or more citations within the network are included. The graph was generated using 'Gephi' (Bastian, Heymann, \& Jacomy, 2009). See the link in the Acknowledgments for the underlying data, a detailed description of the graphing method and a discussion of the limitations of citation analysis. 
The lack of theoretical integration outlined above is apparent when reading the content of experimental and qualitative studies and can also be seen in discussions of the general themes that emerge from those studies. Recent reviews of the design fixation experiments emphasise the presentation of example solutions as stimuli, including the timing of stimuli presentation, their modality, fidelity, novelty, quantity, diversity and 'distance' from the problem (Alipour, Faizi, Moradi, \& Akrami, 2017; Sio et al., 2015; Vasconcelos \& Crilly, 2016). In contrast, the themes emphasised in the relevant case studies and interviews include personal experience, intrinsic motivation, persistence, holistic thinking, depth of enquiry, and iterative sketching, making and testing (see review in Crilly, 2019). It would be possible to make at least some connections here, but because each of these different literatures does not engage with the details of the other, the two different types of study remain separate, whether in terms of background, research design, data analysis, acknowledged limitations or proposed future work. This fits with the general observation that even if qualitative and quantitative researchers use the same terminology to describe some phenomenon of interest, they are often referring to fundamentally different things (Sale, Lohfeld, \& Brazil, 2002, p. 48).

Whilst a clear separation between research conducted by different methods might not be surprising, it is neither necessary nor helpful. For example, there are specific topics in design research and creativity research which have benefitted from combining studies using different methods. Research on 'change management' demonstrates methodological diversity with theoretical integration: industrial case studies and real-world data sets have been produced (e.g. Clarkson, Simons, \& Eckert, 2004; Giffin, de Weck, Bounova, Keller, Eckert, \& Clarkson, 2009; Pikosz \& Malmqvist, 1998) and these are used in subsequent theory development, modelling and tool building work (e.g. Pasqual \& de Weck, 2012; Reddi \& Moon, 2009; Siddharth \& Sarkar, 2017). Design fixation research is starkly different to this, but also different to contemporary creativity research, which has corrected its previously narrow approach. In surveying the history of the field, Mumford (2003) noted that "our overreliance on divergent thinking tests [...] became a real problem unduly limiting the scope of creativity research while raising the specter of method bias in both theory and findings" ( $p$. 108). He reports that the subsequent rise of a wider range of research methods, including historiometrics, neuroscience, interviews and document analysis led to a more complete understanding of people's creative work (for related discussions in other disciplines see Johns 2003, p. 160; Martocchio \& Harrison, 1993). 


\section{Validity and relevance}

Observing that design fixation experiments are seemingly detached from accounts of realworld design activities raises concerns about external validity, a subject of concern for design creativity research (Kazakci, Gillier, Piat, \& Hatchuel, 2015), and for creativity research more generally (Cropley, 2000; Runco, 2017; Wechsler, Vendramini, \& Oakland, 2012). The external validity of research is a complex subject, with many overlapping concepts related to the way in which the design of a study is (or is not) representative of the populations, environments and tasks of interests (for history and discussion, see Araújo, Davids, \& Passos, 2007; Bracht \& Glass, 1968; Schmuckler, 2001). However, here we can limit ourselves to considering how the application of different methods can contribute to the validity of claims that a research community makes about its findings.

For this, Brewer's (2000, p. 3-4) distinction between three different research purposes (and their commonly associated research methods) is useful: (1) empirical demonstration that a phenomenon occurs (most often conducted in the field); (2) identifying causation and not just covariation (most often studied in the laboratory); (3) providing explanation, not just what factor affects what, but why and how (most often studied in the laboratory). Interestingly, for design fixation research, claims about the occurrence of the phenomena of interest (purpose 1) have typically been supported by referring to studies conducted in the laboratory rather than the field. Furthermore, the available field studies (see earlier summary) are not commonly referred to in the laboratory studies that seek causation and explanation (purposes 2 and 3). Comparisons can be made with the related area of ergonomics where there is much closer attention given to the interplay between naturalistic studies of the work context and experimental studies of the underlying phenomena of interest. This interplay is evident in recommendations for enhancing the validity of ergonomic research generally (see Hoc, 2001, pp. 285-286), and ergonomic research of design activities in particular:

"laboratory studies dealing with the design process must demonstrate a sensitivity to the complexity of the real world context by being based upon an understanding of that context. There are at least two ways to achieve an understanding of that context: [...] naturalistic observations of experienced designers engaged in the design process carried out in field settings [...and...] eliciting knowledge about the design process directly from experienced designers" (McNeese, Zaff, Brown, Citera, \& Selvaraj, 1993, pp. 1082-3).

Even though experimental studies need not replicate all the contextual details of the realworld (see Berkowitz \& Donnerstein, 1982; Henshel, 1980), studies of the real world might provide the basis for deciding what people, tasks or contexts are considered most relevant, usefully informing the design of experimental work and the generalizations that are made from them. Conversely, the experimental findings might direct attention to new causal 
relations or underlying mechanisms, inspiring new lines of qualitative enquiry. In illustrating this, Barnard (1991, p. 105) shows that representations of discovery and representations of application mediate between the real world and the scientific understanding of that world. The discovery representation simplifies the real world, constraining the scope of what is assimilated into scientific research, and thereby constraining the possible applications that can later be derived from it (also see models by Ellström, 2007, p. 5; Hevner, 2007, p. 88; Long \& Dowell, 1989, p. 15). These derived applications can take the form of interventions intended to improve the state of things in the world, a process that further informs basic research (for examples from design see Cole, Purao, Rossi, \& Sein, 2005; Shneiderman, 2016; for psychology see Leibowitz, 1996; Medin, 2012).

Neither laboratory studies nor field research (whether basic or applied) are being presented as superior here. Valid or invalid claims might be made from either of them (e.g. see Brewer, 2000 , p. 15; Hoc, 2001, p. 283). In fact, comparative meta-analyses of hundreds of studies in organizational psychology have shown that each approach has its own distinct forms of bias: a bias toward student samples in laboratory studies and toward self-report methods in field research (Dipboye \& Flanagan, 1979, p. 147-148 also see Vanhove \& Harms, 2015, p. 665). Although the claims made about field research can have high external validity for the particular situation being referred to, generalising beyond that situation requires an abstract representation of the phenomena under investigation (see Hoc, 2001, p. 283). Such representations might be derived from theoretical work or experimental studies, which might in turn be informed by fieldwork, and so on. Different kinds of study indicate different phenomena of relevance which allow the validity of claims made from research to be better understood and assessed. The current disconnect between experimental and qualitative research into design fixation makes assessment of validity difficult and means that the inherent weaknesses of different methods are not being mitigated by other approaches (see Mingers \& Brocklesby, 1997, p. 492; also see models by McGrath; 1981, p. 183; Weick, 1979, p. 35).

The belief that different research approaches should be coexist is often referred to as methodological pluralism. Calls for such pluralism can be heard in a wide range of research disciplines, including the Natural Sciences (Chang, 2012), Organisational Science (Knudsen, 2003; Martin, 1993; Podsakoff \& Dalton, 1987), Construction Management (Dainty, 2009; Raftery, McGeorge, \& Walters, 1997), Information Systems (Mingers, 2001), Medical Informatics (Kaplan, 2001), Economics (Norgaard, 1989), Cultural Studies (Phillipov, 2013), Psychology (Crawford \& Kimmel, 1999; Breen \& Darlaston-Jones, 2010), Human Resources (Johns, 2003), Nursing (Rolfe, 1995) and Ergonomics (Hancock \& Szalma, 2004; Hignett \& Wilson, 2004). Similar concerns are also evident in fields that are traditionally constructivist, 
holistic or qualitative, including specific branches of Sociology (Lamont \& Swidler, 2014), Psychology (Frost \& Nolas, 2011) and Cultural Studies (Phillipov, 2013). ${ }^{3}$ In many of these disciplines, arguments for pluralism are motivated by particular features of the subject matter, features which they share with design fixation research. For example, writing of ergonomics, ${ }^{4}$ Hancock and Szalma (2004) argue that "in dealing with human beings, ergonomics is categorically unable to intrinsically limit itself solely to mathematical and quantitative methodologies. Like ethnology and anthropology, ergonomics must seek diverse strategies to comprehend the complexities of behavior in context" (p. 500). This view that understanding human behaviour demands a diverse range of methods is widespread in the human and social sciences (for detailed discussions, see Johns, 2003, p. 160; Perrow, 1994; Rolfe, 1995).

Consideration of the complexity of human behaviour raises another important point: research itself is an example of human behaviour, and one which does not always result in the selection of the most favourable approaches. For example, Knudsen (2003, pp. 263-264) describes the behaviour of a research field in a way that will seem very familiar to those used to thinking about design fixation. He notes that fields with too little pluralism risk being caught in a 'specialization trap', where the search for alternatives is diminished because the exploitation of the normal way of doing things is seemingly effective and efficient. In contrast, fields with too much pluralism risk being caught in a 'fragmentation trap', where there is overwhelming variety in the objectives set and the activities undertaken. These descriptions of specialisation and fragmentation sound a lot like Purcell and Gero's (1996) report on how their two different participant groups behaved in fixation experiments: the mechanical engineering students exhibited "fixation [...] with an example design that embodied principles that formed a part of the knowledge base of that discipline" (p. 379), whereas the industrial design students did not suffer from this problem in the same way but were instead seemingly pursuing novelty for its own sake, "'fixated' on difference" (p. 382). Neither of these behaviours is adaptive, because creativity requires a balance of exploratory breadth and developmental depth: divergence and convergence are both necessary, whether in design, research or other activities (for design see Müller-Wienbergen, Müller, Seidel, \& Becker, 2011; Cropley, 2006, p. 402; for other activities see Cropley, 2006; Oliver, Heracleous, \& Jacobs, 2014). 


\section{Development and adaptability}

Although the application of diverse approaches is seemingly beneficial, academic disciplines are often at their most productive when operating within a well-developed paradigm that establishes consensus for what the subject under investigation is, how it should be studied, what quality standards to apply and how it should be reported. This consensus promotes coordination within the social structures of a discipline, including those structures related to meetings, publications, funding and recruitment (for classic discussions see Kuhn, 1962; Lakatos \& Musgrave, 1970; Polanyi, 1958). Concepts of paradigm development originated in the physical sciences but have also been applied to the human sciences, perhaps most pointedly in Pfeffer's (1993) critical analysis of Organizational Science, where he lists numerous indicators of a field's development, such as the publication of articles rather than books and the citation of recent rather than historic works (p. 601).

Concerns over a low level of paradigm development within design research can be seen in McMahon's (2012) and Cash's (2018) calls for greater levels of coordination in the discipline's theories and methods. For many topics within design research, there is a variety of possible terms and definitions and a sprawling web of relevant work from across many fields and periods. Paradigm development would aim to reduce such fragmentation and tackle competition from outside (for concerns about design research being neglected by other disciplines, see Cash, 2018, p. 85). When considered in these terms, design fixation research might seem to be paradigmatically well developed compared to some other areas of design research. Having a well-defined topic helps with this, as does having a clear intellectual history, both within design research (since the 1990s) and in psychology (since at least the 1940s). Perhaps because of this, work published on design fixation is being cited in management journals such as Management Science (Bayus, 2013), Journal of Marketing Research (Dahl \& Moreau, 2002) and Journal of Product Innovation Management (Hoornaert, Ballings, Malthouse \& Van den Poel, 2017) and psychology journals such as Neuroimage (Beaty, Christensen, Benedek, Silvia, \& Schacter, 2017); Thinking \& Reasoning (Sowden, Pringle, \& Gabora, 2015) and Neuropsychologia (Camarda et al., 2018).

Paradigm development brings many possible benefits, including efficient communication (short articles, low rejection rates, cross-citation) and resource allocation (funding, staffing, collaboration) (see Pfeffer, 1993, pp. 602-607). However, there are also arguments against such development, many of which emphasise that the study of complex human actions and interactions should exhibit more diversity at the expense of coordination (for such claims made specifically in response to Pfeffer's position, see Perrow, 1994). Most of the arguments for methodological pluralism reviewed earlier take this line. In their stronger 
forms, such arguments raise concerns that severe methodological restriction results in a field distorting the subject of interest to suit the methods that have been chosen, even if that choice is driven by implicit ideological commitments (e.g. see Lawson, 2012). In advancing this argument, Mackenzie and House (1978) refer to the 'Type 1' and 'Type 2' errors that much of statistics is generally concerned with, but they indicate that mono-methodological approaches risk another, more critical, type of error which might pass unnoticed: ${ }^{5}$

"Theory building which is restricted to a single setting can become sterile, ingrained, and increasingly arcane. [... By our argument,] The error of working on the wrong problem (examining twigs on a dead branch) is considered more serious than accepting a false hypothesis (calling a twig "alive" when it is not), or rejecting a true hypothesis (calling a twig "dead" when it is alive). Because the error of working on the wrong problem (a type 3 error) is rarely mentioned, even in conversations, and because conventional statistics does not treat this important error, seeking rejections is likely to be efficacious in generating better theory" (p. 21).

Put simply, paradigm development is only productive if the paradigm being developed is relevant. Considering design fixation research in these terms, we might ask if the experiments are targeting the phenomena of most interest, or just the phenomena to which the methods are best suited.

Despite many suggestions that debate and divergence are in opposition to paradigm development, this is not necessarily the case. Pfeffer (1993) lists five issues that a discipline or sub-field might disagree over: (1) the questions that are important; (2) the ways to measure or model the variables; (3) the data collection and analysis methods to be used; (4) the theoretical models of behaviour that guide the research; and (5) the means for determining which approach to the first four issues is most productive. He states that a field disagreeing over all five areas will not make progress of any consequence, but that "Theoretical and methodological diversity may be adaptive as long as there is some agreement over fundamental goals and on a set of rules to winnow the measures, methods, and theories on the basis of accumulated evidence" (p. 616). Given its position of paradigmatic strength, design fixation research could begin to explore more thoroughly some of the questions that Pfeffer lists, although preferably not all of them at once. To be adaptive might require questioning assumptions which have previously proven useful in forming and maintaining consensus.

Concern for whether a field's behaviour is adaptive is at the heart of the matter: methodological diversity and paradigm development can be considered in terms of what will provide the healthiest and most productive foundation for knowledge production. Even though agreement on concepts, methods and theories encourages efficient research in the 
short term, it does not necessarily give rise to the characteristics that permit flexibility under changing circumstances. For example, Norgaard (1989, pp. 49-50) critically compared the multi-methodological approaches applied in ecological research with the monomethodological approaches applied in economics research. The methodologically diverse field of ecology was able to behave flexibly and productively when a focus on the details of individual cases permitted the dominant logic to be questioned and improved. In comparison, the methodologically restricted field of economics adhered to its dominant logic despite valid arguments that those general theories would not hold in specific cases (also see the earlier reference to Knudsen's (2003) point about the long-term risks of a field becoming narrowly specialised).

Interestingly, and somewhat recursively, the example that Norgaard provides in his ecology case is 'diversity-stability' theory, which associates component variety with overall system resilience (McCann, 2000). Such thinking is present in design research and design practice too, especially when considering the design of socio-technical and socio-ecological systems (e.g. see Anderies, 2014; Taysom \& Crilly, 2017). Such work suggests that coordinating a research topic so that it can accommodate unanticipated changes (e.g. new findings, anomalous findings) would require the incorporation of diversity (e.g. different methods, alternative theories). Such diversity would mean going beyond simple distinctions between different kinds of research: field-laboratory or qualitative-quantitative or basic-applied. A wider exploration might require all of these approaches, or others still, or productive combinations of them.

\section{Breadth and depth}

Imagine that the design fixation research community were to recognise a need for increased methodological diversity and theoretical integration. What challenges might it expect to face and how might it overcome them? Well, perhaps just as any study of real design processes recognises that design work does not always adhere to the prescriptions of design textbooks (e.g. see Cross, 2004), it is useful to recognise that real research processes do not always adhere to the prescriptions of methodology textbooks. Whilst it is an axiom of research methodology that the identification of research questions determines the selection of research methods, Martin's (1993, p. 41) analysis of research behavior suggests that methodological preferences (and resource availability) do instead drive question formation. Similar observations are made elsewhere, with concerns that such behavior can hamper a field's ability to impact practice (Podsakoff \& Dalton, 1987, p. 438). 
Researchers' methodological preferences might be influenced by many factors, ranging from fundamental philosophical commitments to more pragmatic issues such as previous training, available funding, publication concerns and career aspirations (Easterbrook, Singer, Storey, \& Damian, 2008, p. 294; Mingers, 2001, p.247; Jaffee, Kling, Plant, Sloan, \& Hyde, 2016, p. 429). However, increasing diversity and integration does not necessarily require researchers to change methods. It might instead require that the application of their preferred methods is informed by the work of other researchers who approach the subject differently. At present this exchange is seemingly not happening very effectively in design fixation, where the themes being discussed in the qualitative and quantitative studies are quite different (see earlier summary). One reason for this might be that different forms of creative design work are being studied. Many of the qualitative studies have focused on lone inventors working on personal projects over very long time periods independently of any externally set 'design brief'. In contrast, many of the experimental studies appear to be representing formal design engagements. If there were more explicit descriptions of the kind of design work that is of interest, then it would be easier to identify and exploit the connections between these different streams of research. Either way, some action would need to be taken to promote the flow of ideas between research conducted by different methods as it is widely reported that such communication is difficult to establish and maintain effectively (Bryman, 2007, p. 21; Greene, Caracelli, \& Graham, 1989, p. 270; Martin, 1993, p42).

Another alternative to researchers adopting different methods is for them to seek collaborations with researchers who specialise in those methods. This would mean the formation of research teams that represent a diversity of disciplines and approaches, possibly including industry partners (for the benefits of such collaborations, see Shneiderman, 2016, p. 157). This suggests that experimental researchers might have research questions that they would like to see addressed but which are not amenable to their preferred methods. These questions might, for example, relate to the work contexts of interest (including variation between contexts), the occurrence of fixation (including the factors which shape such occurrences), the 'market' for interventions (including the preferred forms of such interventions) and matters related to the factors presently being investigated in the experiments (such as exposure to examples, physical prototyping, teamwork). It matters how such questions are formulated, structured, prioritised and communicated because this will influence who can be recruited to address them (see Agee, 2009; Easterbrook, Singer, Storey, \& Damian, 2008: §2). With the right framing, interested researchers might subsequently approach the topic of design fixation from a fresh perspective, connect it to different literatures and employ new research approaches to better understand it. Such work could either take the form of studies which remain independent of experimental work or 
could be incorporated into mixed-method studies that combine multiple approaches. Theoretical integration is not assured either way but is likely to be stronger where the different types of studies are designed in a coordinated manner (Mingers 1997, p. 7; MoranEllis et al., 2006, p. 51; Pluye \& Hong, 2014, p. 30).

It is important to recognise that many of the issues discussed in this article are not the responsibility of any individual researcher and need not be addressed in any individual piece of work. Concerns for diversity, integration, validity, development and application primarily arise within research communities and in the bodies of work that they draw from and contribute to. Although researchers might attend to such matters in specific projects or extended research programmes, they are perhaps most effectively addressed by the institutions through which research is coordinated, whether in the form of journal special issues, conference tracks or funding programmes (Podsakoff \& Dalton, 1987, p. 435). Whether seeking engagement from these research institutions, or seeking influence through practitioners, educators, students or journalists, it is helpful to be able to tell the right kind of stories about the subject matter. For this, it is necessary to have accounts of how design fixation has arisen 'in the wild', what the consequences were, and if and how it was overcome. Because such stories lack the abstraction of more formal research outputs they can attract the attention of diverse audiences and help to generate interest in, or even explain, those other outputs (Sayer \& Lee, 2014, p. 1275; Sherman \& Strang, 2004, p. 211).

My purpose with this article is to stimulate discussion on these topics, whether amongst individuals or at an institutional level. Such discussions might focus on design fixation in particular, other topics in design research or research elsewhere. Over the last forty years, discussions of this kind seem to have declined, even as methodological rigour has increased, or perhaps because of that. Studies of how institutions, groups and individuals behave tell us that increased experience with an approach improves performance within that limited scope but can decrease flexibility in identifying and applying other approaches (Sternberg, 1996; but also see Bilalić, McLeod, \& Gobet, 2008). This is the sort of thing that design fixation researchers know about, knowledge which they might use to inform the study of their own collective behaviour, encouraging wider and deeper explorations. Given that research is designed and that such design work can suffer from fixation, it might also be that design fixation research is well placed to inform the behaviour of other research disciplines, encouraging new explorations there also. 


\section{Acknowledgments}

Thank you to Nigel Cross for the invitation to submit a paper to this issue and for his helpful comments on earlier drafts. Thanks also to audiences at the University of Cambridge and TU Delft, and Philip Barnard (MRC Cognition and Brain Sciences Unit), Carlos Cardoso (lowa State University), Philip Cash (Danish Technical University) and Robert J. Youmans (Google Inc.) for useful discussions. I am grateful to Graham Crow (University of Edinburgh) for the introduction to the topic of methodological pluralism, and Christopher May and Patrick Montjourides (both University of Cambridge) for guidance on citation network analysis. This work was partly supported by the UK's Engineering and Physical Sciences Research Council (EP/K008196/1) all the raw data is available in the cited material, with the citation mapping data available from the University of Cambridge repository at https://doi.org/10.17863/CAM.44399. 


\section{References}

Agee, J. (2009). Developing qualitative research questions: a reflective process. International Journal of Qualitative Studies in Education, 22(4), 431-447. https://doi.org/10.1080/09518390902736512

Agogué, M., Kazakçi, A., Hatchuel, A., Le Masson, P., Weil, B., Poirel, N., \& Cassotti, M. (2014). The Impact of Type of Examples on Originality: Explaining Fixation and Stimulation Effects. The Journal of Creative Behavior, 48(1), 1-12. https://doi.org/10.1002/jocb.37

Alipour, L., Faizi, M., Moradi, A. M., \& Akrami, G. (2017). A review of design fixation: research directions and key factors. International Journal of Design Creativity and Innovation, 6(1-2), 1-14. https://doi.org/10.1080/21650349.2017.1320232

Anderies, J. M. (2014). Embedding built environments in social-ecological systems: resilience-based design principles. Building Research \& Information, 42(2), 130-142. https://doi.org/10.1080/09613218.2013.857455

Araújo, D., Davids, K., \& Passos, P. (2007). Ecological Validity, Representative Design, and Correspondence Between Experimental Task Constraints and Behavioral Setting: Comment on. Ecological Psychology, 19(1), 69-78. https://doi.org/10.1080/10407410709336951

Badke-Schaub, P. (2013). A pleading for a holistic research approach of creativity and innovation in design [in Perspectives on design creativity and innovation research (Editorial board of IJDCI)]. International Journal of Design Creativity and Innovation, 1(1), 1-42.

Ball, L. J., \& Christensen, B. T. (2018). Designing in the wild. Design Studies, 57, 1-8. https://doi.org/10.1016/i.destud.2018.05.001

Barnard, P. (1991). Bridging between basic theories and the artifacts of human-computer interaction. In J. M. Carroll (Ed.), Designing Interaction, New York, NY: Cambridge University Press, (pp. 103-127).

Bastian M., Heymann S., \& Jacomy M. (2009). Gephi: an open source software for exploring and manipulating networks. International AAAI Conference on Weblogs and Social Media. San Jose, CA. [https://gephi.org/ accessed 20/04/2019]

Bayus, B. L. (2013). Crowdsourcing new product ideas over time: An analysis of the Dell IdeaStorm community. Management science, 59(1), 226-244.

Beaty, R. E., Christensen, A. P., Benedek, M., Silvia, P. J., \& Schacter, D. L. (2017). Creative constraints: Brain activity and network dynamics underlying semantic interference during idea production. Neuroimage, 148, 189-196.

Berkowitz, L., \& Donnerstein, E. (1982). External validity is more than skin deep: Some answers to criticisms of laboratory experiments. American Psychologist, 37(3), 245257. https://doi.org/10.1037/0003-066X.37.3.245

Bessant, J. R. (1979). Preparing for design studies: ways of watching: Notes towards appropriate methodology for studying functional specialists. Design Studies, 1(2), 7783. https://doi.org/10.1016/0142-694X(79)90003-6 
Bessant, J. R., \& McMahon, B. J. (1979). Participant observation of a major design decision in industry. Design Studies, 1(1), 21-26. https://doi.org/10.1016/0142-694X(79)90024-3

Bilalić, M., McLeod, P., \& Gobet, F. (2008). Inflexibility of experts-Reality or myth? Quantifying the Einstellung effect in chess masters. Cognitive Psychology, 56(2), 73102. https://doi.org/10.1016/j.cogpsych.2007.02.001

Blessing, L. T. M., \& Chakrabarti, A. (2009). DRM, a Design Research Methodology. London, UK: Springer-Verlag.

Bracht, G. H., \& Glass, G. V. (1968). The External Validity of Experiments. American Educational Research, 5(4), 438-474.

Brattinga, P. (1964). Industrial Design in the Netherlands. Design Quarterly, 59, 1-25. https://doi.org/10.2307/4047295

Breen, D. L. J., \& Darlaston-Jones, D. (2010). Moving beyond the enduring dominance of positivism in psychological research: Implications for psychology in Australia. Australian Psychologist, 45(1), 67-76.https://doi.org/10.1080/00050060903127481

Brewer, M. B. (2000). Research design and the issue of validity. In H. T. Reis \& C. M. Judd (Eds.), Handbook of Research Methods in Social and Personality Psychology (pp. 316). Cambridge University Press.

Bryman, A. (2007). Barriers to integrating quantitative and qualitative research. Journal of Mixed Methods Research, 1(1), 8-22.

Busby, J. A., \& Lloyd, P. A. (1999a). Influences on Solution Search Processes in Design Organisations. Research in Engineering Design, 11(3), 158-171. https://doi.org/10.1007/s001630050012

Busby, J. S., \& Lloyd, P. A. (1999b). Does experience enable or impede the design process? Engineering Management Journal, 9(3), 137-142. https://doi.org/10.1049/em:19990312

Camarda, A., Salvia, E., Vidal, J., Weil, B., Poirel, N., Houde, O., ... \& Cassotti, M. (2018). Neural basis of functional fixedness during creative idea generation: an EEG study. Neuropsychologia, 118, 4-12.

Candy, L., \& Edmonds, E. (1996). Creative design of the Lotus bicycle: implications for knowledge support systems research. Design Studies, 17(1), 71-90.

Cardoso, C., \& Badke-Schaub, P. (2011). The influence of different pictorial representations during idea generation. The Journal of Creative Behavior, 45(2), 130-146.

Carroll, J. M., Thomas, J. C., \& Malhotra, A. (1979). Clinical-experimental analysis of design problem solving. Design Studies, 1(2), 84-92. https://doi.org/10.1016/0142$\underline{694 \times(79) 90004-8}$

Cash, P. J. (2018). Developing theory-driven design research. Design Studies, 56, 84-119. https://doi.org/10.1016/j.destud.2018.03.002

Cash, P. J., Hicks, B. J., \& Culley, S. J. (2013). A comparison of designer activity using core design situations in the laboratory and practice. Design Studies, 34(5), 575-611. https://doi.org/10.1016/j.destud.2013.03.002 
Chan, J., Fu, K., Schunn, C., Cagan, J., Wood, K., \& Kotovsky, K. (2011). On the Benefits and Pitfalls of Analogies for Innovative Design: Ideation Performance Based on Analogical Distance, Commonness, and Modality of Examples. Journal of Mechanical Design, 133(8), 081004-081004-081011. https://doi.org/10.1115/1.4004396

Chang, H. (2012). Is Water $\mathrm{H}_{2} \mathrm{O}$ ? Evidence, Realism and Pluralism. Heidelberg, Germany: Springer.

Cheng, P., Mugge, R., \& Schoormans, J. P. L. (2014). A new strategy to reduce design fixation, presenting partial photographs to designers. Design Studies, 35(4), 374-391.

Chrysikou, E. G., \& Weisberg, R. W. (2005). Following the wrong footsteps: fixation effects of pictorial examples in a design problem-solving task. Journal of Experimental Psychology: Learning, Memory, and Cognition, 31(5), 1134-1148.

Clarkson, P. J., Simons, C., \& Eckert, C. (2004). Predicting Change Propagation in Complex Design. Journal of Mechanical Design, 126(5), 788-797.

Cole, R., Purao, S., Rossi, M., \& Sein, M. (2005). Being Proactive: Where Action Research Meets Design Research. ICIS2005 Proceedings, 325-336.

Cooke, P. (2001). Regional Innovation Systems, Clusters, and the Knowledge Economy. Industrial and Corporate Change, 10(4), 945-974. https://doi.org/10.1093/icc/10.4.945

Crawford, M., \& Kimmel, E. (1999). Promoting Methodological Diversity in Feminist Research. Psychology of Women Quarterly, 23(1), 1-6. https://doi.org/10.1111/j.14716402.1999.tb00337.x

Crilly, N. (2015). Fixation and creativity in concept development: The attitudes and practices of expert designers. Design Studies, 38, 54-91. https://doi.org/10.1016/j.destud.2015.01.002

Crilly, N. (2019). Creativity and fixation in the real world: a literature review of case study research. Design Studies. https://doi.org/10.1016/j.destud.2019.07.002

Crilly, N., \& Cardoso, C. (2017). Where next for research on fixation, inspiration and creativity in design? Design Studies, 50, 1-38. https://doi.org/10.1016/j.destud.2017.02.001

Crilly, N. \& Moroşanu Firth, R. (2019) Creativity and fixation in the real world: three case studies of invention, design and innovation. Design Studies. https://doi.org/10.1016/j.destud.2019.07.003

Cropley, A. J. (2000). Defining and measuring creativity: Are creativity tests worth using? Roeper Review, 23(2), 72-79. https://doi.org/10.1080/02783190009554069

Cropley, A. (2006). In Praise of Convergent Thinking. Creativity Research Journal, 18(3), 391-404. https://doi.org/10.1207/s15326934crj1803 13

Cropley, D., \& Cropley, A. (2010). Recognizing and fostering creativity in technological design education. International Journal of Technology and Design Education, 20(3), 345-358. https://doi.org/10.1007/s10798-009-9089-5 
Cross, N. (2001). Achieving Pleasure from Purpose the Methods of Kenneth Grange, Product Designer. The Design Journal, 4 (1), 48-58.

Cross, N. (2004). Expertise in design: an overview. Design Studies, 25(5), 427-441.

Cross, N., \& Clayburn Cross, A. (1996). Winning by design: the methods of Gordon Murray, racing car designer. Design Studies, 17(1), 91-107.

Dahl, D. W., \& Moreau, P. (2002). The influence and value of analogical thinking during new product ideation. Journal of Marketing Research, 39(1), 47-60.

Dainty, A. (2009). Methodological pluralism in construction management research. In A. Knight \& L. Ruddock (Eds.), Advanced Research Methods in the Built Environment (pp. 1-13). Wiley-Blackwell.

Darke, J. (1979). The primary generator and the design process. Design Studies, 1(1), 3644.

Demirkan, H., \& Afacan, Y. (2012). Assessing creativity in design education: Analysis of creativity factors in the first-year design studio. Design Studies, 33(3), 262-278. https://doi.org/10.1016/j.destud.2011.11.005

Dipboye, R. L., \& Flanagan, M. F. (1979). Research settings in industrial and organizational psychology: Are findings in the field more generalizable than in the laboratory? American Psychologist, 34(2), 141-150. https://doi.org/10.1037/0003-066X.34.2.141

Dorst, K. (in press). Co-evolution and the emergence of order. Design Studies.

Dunbar, K. (2001). The analogical paradox: Why analogy is so easy in naturalistic settings, yet so difficult in the psychological laboratory. In D. Gentner, K. J. Holyoak, \& B. N. Kokinov (Eds.), The analogical mind, perspectives from cognitive science (pp. 313334). Cambridge, MA: MIT Press.

Easterbrook, S., Singer, J., Storey, M.-A., \& Damian, D. (2008). Selecting Empirical Methods for Software Engineering Research. In F. Shull, J. Singer, \& D. I. K. Sjøberg (Eds.), Guide to Advanced Empirical Software Engineering (pp. 285-311). https://doi.org/10.1007/978-1-84800-044-5 11

Eckert, C., \& Stacey, M. (2000). Sources of inspiration: a language of design. Design Studies, 21(5), 523-538.

Eckert, C. M., Stacey, M., \& Earl, C. (2005). References to past designs. In J. S. Gero \& N. Bonnardel (Eds.), Studying designers (pp. 3-21). University of Provence, Aix-enProvence, France.

Ekvall, G. (1996). Organizational climate for creativity and innovation. European Journal of Work and Organizational Psychology, 5(1), 105-123.

https://doi.org/10.1080/13594329608414845

Ellström, P.-E. (2007). Knowledge Creation Through Interactive Research: A Learning Perspective. Paper presented at HHS-07. Sweden: Jönköping University, 2007.

Henshel, R. L. (1980). The purposes of laboratory experimentation and the virtues of deliberate artificiality. Journal of Experimental Social Psychology, 16(5), 466-478. https://doi.org/10.1016/0022-1031(80)90052-9 
Hevner, A. R. (2007). A Three Cycle View of Design Science Research. Scandinavian Journal of Information Systems, 19(2), 87-92.

French, M. J. (1971/1998). Conceptual Design for Engineers (3rd ed.). Springer.

Frost, N. A., \& Nolas, S.-M. (2011). Exploring and Expanding on Pluralism in Qualitative Research in Psychology. Qualitative Research in Psychology, 8(2), 115-119. https://doi.org/10.1080/14780887.2011.572728

Fu, K., Chan, J., Cagan, J., Kotovsky, K., Schunn, C., \& Wood, K. (2013). The meaning of "near" and "far": the impact of structuring design databases and the effect of distance of analogy on design output. Journal of Mechanical Design, 135(2), 021007.

Garvin, W. L. (1964). Creativity and the Design Process. Journal of Architectural Education, 19(1), 3-4.

Gero, J. S. (1990). Design prototypes: a knowledge representation schema for design. Al Magazine, 11(4), 26-36.

Giffin, M., de Weck, O., Bounova, G., Keller, R., Eckert, C., \& Clarkson, P. J. (2009). Change Propagation Analysis in Complex Technical Systems. Journal of Mechanical Design, 131(8), 081001-081001-081014.

Goldschmidt, G., \& Smolkov, M. (2006). Variances in the impact of visual stimuli on design problem solving performance. Design Studies, 27(5), 549-569. https://doi.org/10.1016/j.destud.2006.01.002

Goldschmidt, G., \& Tatsa, D. (2005). How good are good ideas? Correlates of design creativity. Design Studies, 26(6), 593-611. https://doi.org/10.1016/j.destud.2005.02.004

Goucher-Lambert, K., Moss, J., \& Cagan, J. (2019). A neuroimaging investigation of design ideation with and without inspirational stimuli-understanding the meaning of near and far stimuli. Design Studies, 60, 1-38.

Greene, J. C., Caracelli, V. J., \& Graham, W. F. (1989). Toward a conceptual framework for mixed-method evaluation designs. Educational evaluation and policy analysis, 11(3), 255-274.

Hancock, P. A., \& Szalma, J. L. (2004). On the relevance of qualitative methods for ergonomics. Theoretical Issues in Ergonomics Science, 5(6), 499-506. https://doi.org/10.1080/14639220412331303391

Herring, S. R., Chang, C.-C., Krantzler, J., \& Bailey, B. P. (2009). Getting inspired!: understanding how and why examples are used in creative design practice. In Proceedings of the SIGCHI Conference on Human Factors in Computing Systems (pp. 87-96). ACM.

Henderson, K. (1999). On Line and On Paper: Visual representations, visual culture, and computer graphics in design engineering. Cambridge, MA: The MIT Press.

Heylighen, A., \& Neuckermans, H. (2002). Are Architects Natural Case-Based Designers? Experts Speaking. The Design Journal, 5(2), 8-22. https://doi.org/10.2752/146069202790718521 
Heylighen, A., \& Verstijnen, I. M. (2003). Close encounters of the architectural kind. Design Studies, 24(4), 313-326. https://doi.org/10.1016/S0142-694X(02)00040-6

Hickman, R. P. \& Roos, M. J. (1982) 'Workmate', CIPA Journal, July: 424-457. London, UK: Chartered Institute of Patent Attorneys.

Hignett, S., \& Wilson, J. R. (2004). The role for qualitative methodology in ergonomics: a case study to explore theoretical issues. Theoretical Issues in Ergonomics Science, 5(6), 473-493. https://doi.org/10.1080/14639220412331303382

Hoc, J.-M. (2001). Towards ecological validity of research in cognitive ergonomics. Theoretical Issues in Ergonomics Science, 2(3), 278-288. https://doi.org/10.1080/14639220110104970

Hoornaert, S., Ballings, M., Malthouse, E. C., \& Van den Poel, D. (2017). Identifying New Product Ideas: Waiting for the Wisdom of the Crowd or Screening Ideas in Real Time. Journal of Product Innovation Management, 34(5), 580-597. https://doi.org/10.1111/jpim.12396

Howard, T. J., Culley, S. J., \& Dekoninck, E. (2008). Describing the creative design process by the integration of engineering design and cognitive psychology literature. Design Studies, 29(2), 160-180.

Hubka, V. (1982). Principles of Engineering Design (English trans.). London, UK: Butterworth \& Co. [First pub. 1980 in German: Konstruktionstaktik = Methoden + Grundsätze des Konstrukteures; Schweizer Maechinenmarkt]

Hubka, V. (1983). Design tactics $=$ methods + working principles for design engineers. Design Studies, 4(3), 188-195. https://doi.org/10.1016/0142-694X(83)90029-7

Jaffee, S., Kling, K. C., Plant, E. A., Sloan, M., \& Hyde, J. S. (2016). The View From Down Here: Feminist Graduate Students Consider Innovative Methodologies. Psychology of Women Quarterly. Retrieved from https://journals.sagepub.com/doi/pdf/10.1111/j.14716402.1999.tb00373.x

Janesick, V. J. (1998). The dance of qualitative research design: Metaphor, methodolatry, and meaning. In N. K. Denzin \& Y. S. Lincoln (Eds.), Handbook of qualitative research (pp. 35-55). Thousand Oaks, CA, US: Sage Publications, Inc.

Jansson, D. G., \& Smith, S. M. (1989). Design fixation. Engineering Design Research Conference, National Science Foundation, 53-76.

Jansson, D. G., \& Smith, S. M. (1991). Design fixation. Design Studies, 12(1), 3-11.

Johns, G. (2003). How methodological diversity has improved our understanding of absenteeism from work. Human Resource Management Review, 13(2), 157-184. https://doi.org/10.1016/S1053-4822(03)00011-1

Kaplan, B. (2001). Evaluating informatics applications—some alternative approaches: theory, social interactionism, and call for methodological pluralism. International Journal of Medical Informatics, 64(1), 39-56.

Kara, H. (2015). Creative Research Methods in the Social Sciences: A Practical Guide. Bristol, UK: Policy Press. 
Kazakci, A. O., Gillier, T., Piat, G., \& Hatchuel, A. (2015). Brainstorming vs. Creative Design Reasoning: A Theory-Driven Experimental Investigation of Novelty, Feasibility and Value of Ideas. In J. S. Gero \& S. Hanna (Eds.), Design Computing and Cognition '14 (pp. 173-188). Springer International Publishing.

Keller, A. I., Pasman, G. J., \& Stappers, P. J. (2006). Collections designers keep: Collecting visual material for inspiration and reference. CoDesign, 2(1), 17-33. https://doi.org/10.1080/15710880600571123.

Kimball, A. W. (1957). Errors of the Third Kind in Statistical Consulting. Journal of the American Statistical Association, 52(278), 133-142. https://doi.org/10.2307/2280840

Knudsen, C. (2003). Pluralism, scientific progress, and the structure of organization theory. In H. Tsoukas \& C. Knudsen (Eds.), The Oxford Handbook of Organization Theory (pp. 237-261). Oxford, UK: Oxford University Press.

Kuhn, T. S. (1962). The structure of scientific revolutions. Chicago: University of Chicago Press.

Lakatos, I., \& Musgrave, A. (Eds.). (1970). Criticism and the Growth of Knowledge, proceedings of the International Colloquium in the Philosophy of Science, London, 1965, Volume 4. Cambridge, UK: Cambridge University Press.

Lamont, M., \& Swidler, A. (2014). Methodological Pluralism and the Possibilities and Limits of Interviewing. Qualitative Sociology, 37(2), 153-171. https://doi.org/10.1007/s11133$\underline{014-9274-z}$

Landis, S. (1998). The Workbench Book: A Craftsman's Guide to Workbenches for Every Type of Woodworking. New Town, CT: The Taunton Press, Inc.

Lawson, B. (1980). How designers think. London, UK: The Architectural Press.

Lawson, B. (1994). Design in Mind. Oxford, UK: Butterworth-Heinemann.

Lawson, T. (2012). Mathematical Modelling and Ideology in the Economics Academy: Competing explanations of the failings of the modern discipline? Economic Thought, $1(1), 1-22$.

Leibowitz, H. W. (1996). The symbiosis between basic and applied research. The American Psychologist, 51(4), 366-370.

Lewis, W. P., \& Samuel, A. E. (1989). Fundamentals of engineering design. Prentice Hall.

Liikkanen, L. A., \& Perttula, M. (2010). Inspiring design idea generation: Insights from a memory-search perspective. Journal of Engineering Design, 21(5), 545-560. https://doi.org/10.1080/09544820802353297

Linnebank, F. E., Kindt, M., \& de Wit, S. (2018). Investigating the balance between goaldirected and habitual control in experimental and real-life settings. Learning \& Behavior, 46(3), 306-319. https://doi.org/10.3758/s13420-018-0313-6

Linsey, J. (2013). Advancing the scholarship of design creativity research [in Perspectives on design creativity and innovation research (Editorial board of IJDCI)]. International Journal of Design Creativity and Innovation, 1(1), 1-42. 
Linsey, J. S., Tseng, I., Fu, K., Cagan, J., Wood, K. L., \& Schunn, C. (2010). A study of design fixation, its mitigation and perception in engineering design faculty. Journal of Mechanical Design, 132(4), 041003.

Linsey, J. S., Wessen, R., \& Ziemer, J. (2016). Observations of a highly innovative group Directions for future research. The Fourth International Conference on Design Creativity, 1-9. Atlanta, GA.

Long, J., \& Dowell, J. (1989). Conceptions of the discipline of HCl: Craft, Applied Science, and Engineering. In Sutcliffe, A. \& Macaulay, L., (eds.) People and Computers V: Proceedings of the Fifth Conference of the British Computer Society. (pp. pp. 9-32). Cambridge University Press: Cambridge, UK.

Marien, H., Custers, R., \& Aarts, H. (2019). Studying Human Habits in Societal Context: Examining Support for a Basic Stimulus-Response Mechanism. Current Directions in Psychological Science, 1-5. https://doi.org/10.1177/0963721419868211

Martocchio, J. J., \& Harrison, D. A. (1993). To be there or not to be there? Questions, theories and methods in absenteeism research. Research in Personnel and Human Resources Management, 11, 259-328.

Mason, J., \& Dale, A. (2011). Creative Tensions in Social Research: Questions of Method. In A. Dale \& J. Mason (Eds.), Understanding Social Research: Thinking Creatively about Method (pp. 1-26). Los Angeles, CA: SAGE.

Mauldin, R. G. (1988). Design fixation: an inhibition of creativity and quality in engineering design (PhD Thesis, Texas A\&M University).

Martin, J. (1993). Breaking up the mono-method monopolies in organisational analysis. In J. Hassard \& D. Pym (Eds.), The Theory and Philosophy of Organizations: Critical Issues and New Perspectives (pp. 30-43). London: Routledge.

Mackenzie, K. D., \& House, R. (1978). Paradigm Development in the Social Sciences: A Proposed Research Strategy. Academy of Management Review, 3(1), 7-23.

McCann, K. S. (2000). The diversity-stability debate. Nature, 405(6783), 228-233. https://doi.org/10.1038/35012234

McGrath, J. E. (1981). Dilemmatics: The Study of Research Choices and Dilemmas. American Behavioral Scientist, 25(2), 179-210. https://doi.org/10.1177/000276428102500205

McMahon, C. A. (2012). Reflections on diversity in design research. Journal of Engineering Design, 23(8), 563-576. https://doi.org/10.1080/09544828.2012.676634

McNeese, M. D., Zaff, B. S., Brown, C. E., Citera, M., \& Selvaraj, J. (1993). Understanding the Context of Multidisciplinary Design: Establishing Ecological Validity in the Study of Design Problem Solving. Proceedings of the Human Factors and Ergonomics Society Annual Meeting, 37(16), 1082-1086. https://doi.org/10.1177/154193129303701609

Medin, D. L. (2012). A Dangerous Dichotomy: Basic and Applied Research. APS Observer, 25(3). Retrieved from https://www.psychologicalscience.org/observer/a-dangerousdichotomy-basic-and-applied-research 
Mingers, J. (1997). Multi-paradigm Multimethodology. In J. Mingers \& A. Gill (Eds.), Multimethodology: the theory and practice of combining management science methodologies (pp. 1-20). Chichester, UK: Wiley.

Mingers, J. (2001). Combining IS Research Methods: Towards a Pluralist Methodology. Information Systems Research, 12(3), 240-259. https://doi.org/10.1287/isre.12.3.240.9709

Mingers, J., \& Brocklesby, J. (1997). Multimethodology: Towards a framework for mixing methodologies. Omega, 25(5), 489-509. https://doi.org/10.1016/S0305-0483(97)00018$\underline{2}$

Moran-Ellis, J., Alexander, V. D., Cronin, A., Dickinson, M., Fielding, J., Sleney, J., \& Thomas, H. (2006). Triangulation and integration, processes, claims and implications. Qualitative Research, 6(1), 45-59.

Moreno, D. P., Blessing, L. T., Yang, M. C., Hernández, A. A., \& Wood, K. L. (2016). Overcoming design fixation: Design by analogy studies and nonintuitive findings. Artificial Intelligence for Engineering Design, Analysis and Manufacturing, 30(02), 185199. https://doi.org/10.1017/S0890060416000068

Moreno, D. P., Hernández, A. A., Yang, M. C., Otto, K. N., Hölttä-Otto, K., Linsey, J. S., \& Linden, A. (2014). Fundamental studies in design-by- analogy: a focus on domainknowledge experts and applications to transactional design problems. Design Studies, 35(3), 232-272.

Morgan, G. A., Gliner, J. A., \& Harmon (1999). Definition, Purposes, and Dimensions of Research. Journal of the American Academy of Child \& Adolescent Psychiatry, 38(2), 217-219. https://doi.org/10.1097/00004583-199902000-00023

Müller-Wienbergen, F., Müller, O., Seidel, S., \& Becker, J. (2011). Leaving the Beaten Tracks in Creative Work - A Design Theory for Systems that Support Convergent and Divergent Thinking. Journal of the Association for Information Systems, 12(11), 714740. https://doi.org/10.17705/1jais.00280

Mumford, M. D. (2003). Where Have We Been, Where Are We Going? Taking Stock in Creativity Research. Creativity Research Journal, 15(2-3), 107-120. https://doi.org/10.1080/10400419.2003.9651403

Nature Editorial (2015). Let's think about cognitive bias. Nature News, 526(7572), 163. https://doi.org/10.1038/526163a

Neroni, M. A., \& Crilly, N. (2019). Whose ideas are most fixating, your own or other people's? The effect of idea agency on subsequent design behaviour. Design Studies, $60,180-212$.

Newell, A., Shaw, J. C., \& Simon, H. A. (1962). The process of creative thinking. In H. E. Gruber \& M. Wertheimer (Eds.), Contemporary approaches to creative thinking: a symposium held at the University of Colorado. New York, NY: Atherton Press.

Nijstad, B. A., Stroebe, W., \& Lodewijkx, H. F. M. (2002). Cognitive stimulation and interference in groups: Exposure effects in an idea generation task. Journal of Experimental Social Psychology, 38(6), 535-544. https://doi.org/10.1016/S0022$\underline{1031(02) 00500-0}$ 
Norgaard, R. B. (1989). The case for methodological pluralism. Ecological Economics, 1(1), 37-57.

Nuzzo, R. (2015). How scientists fool themselves - and how they can stop. Nature News, 526(7572), 182. https://doi.org/10.1038/526182a

Oliver, D., Heracleous, L., \& Jacobs, C. D. (2014). Balancing Divergence and Convergence: Stimulating Creativity through hybrid thinking. In C. Bilton \& S. Cummings (Eds.), Handbook of Management and Creativity (pp. 325-345). Edward Elgar Publishing.

Pasqual, M. C., \& de Weck, O. L. (2012). Multilayer network model for analysis and management of change propagation. Research in Engineering Design, 23(4), 305-328. https://doi.org/10.1007/s00163-011-0125-6

Perrow, C. (1994). Pfeffer Slips! The Academy of Management Review, 19(2), 191-194.

Pfeffer, J. (1993). Barriers to the Advance of Organizational Science, paradigm Development as a Dependent Variable. Academy of Management Review, 18(4), 599-620. https://doi.org/10.5465/amr.1993.9402210152

Phillipov, M. (2013). In Defense of Textual Analysis: Resisting Methodological Hegemony in Media and Cultural Studies. Critical Studies in Media Communication, 30(3), 209-223. https://doi.org/10.1080/15295036.2011.639380

Pikosz P. \& Malmqvist, J. (1998) A comparative study of engineering change management in three Swedish engineering companies. In: ASME design engineering technical conference, Atlanta, GA.

Pluye, P., \& Hong, Q. N. (2014). Combining the Power of Stories and the Power of Numbers: Mixed Methods Research and Mixed Studies Reviews. Annual Review of Public Health, 35(1), 29-45. https://doi.org/10.1146/annurev-publhealth-032013-182440

Podsakoff, P. M., \& Dalton, D. R. (1987). Research Methodology in Organizational Studies. Journal of Management, 13(2), 419-441. https://doi.org/10.1177/014920638701300213

Polanyi, M. (1958). Personal knowledge. London: Routledge \& Kegan Paul.

Purcell, A. T., \& Gero, J. S. (1992). Effects of examples on the results of a design activity. Knowledge-Based Systems, 5(1), 82-91.

Purcell, A. T., \& Gero, J. S. (1996). Design and other types of fixation. Design Studies, 17(4), 363-383.

Purcell, A. T., Williams, P., Gero, J. S., \& Colbron, B. (1993). Fixation Effects: Do They Exist in Design Problem Solving? Environment and Planning B: Planning and Design, 20(3), 333-345. https://doi.org/10.1068/b200333

Raftery, J., McGeorge, D., \& Walters, M. (1997). Breaking up methodological monopolies: a multi-paradigm approach to construction management research. Construction Management and Economics, 15(3), 291-297. https://doi.org/10.1080/014461997373024

Reddi, K., \& Moon, Y. (2009). A framework for managing engineering change propagation. Mechanical and Aerospace Engineering, 7. Retrieved from https://surface.syr.edu/mae/7 
Reich, Y. (2017). The principle of reflexive practice. Design Science, 3. https://doi.org/10.1017/dsj.2017.3

Rittel, H. (1971). Some Principles for the Design of an Educational System for Design. Journal of Architectural Education, 26(1-2), 16-27. https://doi.org/10.1080/10464883.1971.11102482

Robertson, B., \& Radcliffe, D. (2006). The Role of Software Tools in Influencing Creative Problem Solving in Engineering Design and Education. Proceedings of ASME 2006 (IDETC/CIE), 999-1007. https://doi.org/10.1115/DETC2006-99343

Robertson, B. F., \& Radcliffe, D. F. (2009). Impact of CAD tools on creative problem solving in engineering design. Computer-Aided Design, 41(3), 136-146. https://doi.org/10.1016/j.cad.2008.06.007

Rolfe, G. (1995). Playing at research: methodological pluralism and the creative researcher. Journal of Psychiatric and Mental Health Nursing, 2(2), 105-109.

Roy, R. (1993). Case studies of creativity in innovative product development. Design Studies, 14(4), 423-443.

Runco, M. A. (2015). Meta-Creativity: Being Creative About Creativity. Creativity Research Journal, 27(3), 295-298. https://doi.org/10.1080/10400419.2015.1065134

Runco, M. A. (2017). Comments on Where the Creativity Research Has Been and Where Is It Going. The Journal of Creative Behavior, 51(4), 308-313. https://doi.org/10.1002/jocb.189

Runco, M. A., \& Jaeger, G. J. (2012). The Standard Definition of Creativity. Creativity Research Journal, 24(1), 92-96. https://doi.org/10.1080/10400419.2012.650092

Rogers, E. M. (1983). Diffusion of Innovations. London, UK: Free Press.

Runco, M. A. (2015). Meta-Creativity: Being Creative About Creativity. Creativity Research Journal, 27(3), 295-298. https://doi.org/10.1080/10400419.2015.1065134

Runco, M. A. (2017). Comments on Where the Creativity Research Has Been and Where Is It Going. The Journal of Creative Behavior, 51(4), 308-313. https://doi.org/10.1002/jocb.189

Sale, J. E., Lohfeld, L. H., \& Brazil, K. (2002). Revisiting the quantitative-qualitative debate: Implications for mixed-methods research. Quality and quantity, 36(1), 43-53.

Sarkar, P., \& Chakrabarti, A. (2008). The effect of representation of triggers on design outcomes. Al EDAM, 22(02). https://doi.org/10.1017/S0890060408000073

Sayer, C., \& Lee, T. H. (2014). Time after Time-Health Policy Implications of a ThreeGeneration Case Study. New England Journal of Medicine, 371(14), 1273-1276. https://doi.org/10.1056/NEJMp1407153

Schmuckler, M. A. (2001). What Is Ecological Validity? A Dimensional Analysis. Infancy, 2(4), 419-436. https://doi.org/10.1207/S15327078IN0204 02 
Sherman, L. W., \& Strang, H. (2004). Experimental Ethnography: The Marriage of Qualitative and Quantitative Research. The ANNALS of the American Academy of Political and Social Science, 595(1), 204-222. https://doi.org/10.1177/0002716204267481

Shneiderman, B. (2016). The New ABCs of Research: Achieving Breakthrough Collaborations. Oxford, UK: Oxford University Press.

Siddharth, L., \& Sarkar, P. (2017). A Methodology for Predicting the Effect of Engineering Design Changes. Procedia CIRP, 60, 452-457. https://doi.org/10.1016/i.procir.2017.03.071

Sio, U. N., Kotovsky, K., \& Cagan, J. (2015). Fixation or inspiration? A meta-analytic review of the role of examples on design processes. Design Studies, 39, 70-99. https://doi.org/10.1016/j.destud.2015.04.004

Smith, S. M. (2013). Design creativity: a theoretical and empirical science [in Perspectives on design creativity and innovation research (Editorial board of IJDCI)]. International Journal of Design Creativity and Innovation, 1(1), 1-42.

Sowden, P. T., Pringle, A., \& Gabora, L. (2015). The shifting sands of creative thinking: Connections to dual-process theory. Thinking \& Reasoning, 21(1), 40-60.

Sternberg, R. J. (1996). Costs of expertise. In K. A. Ericsson (ed), The road to excellence: The acquisition of expert performance in the arts and sciences, sports, and games (pp. 347-354). Hillsdale, NJ: Lawrence Erlbaum Associates.

Perttula, M., \& Sipilä, P. (2007). The idea exposure paradigm in design idea generation. Journal of Engineering Design, 18(1), 93-102. https://doi.org/10.1080/09544820600679679

Taylor, C., \& Coffey, A. (2009). Editorial - Special issue: qualitative research and methodological innovation. Qualitative Research, 9(5), 523-526. https://doi.org/10.1177/1468794109350355

Taysom, E., \& Crilly, N. (2017). Resilience in Sociotechnical Systems: The Perspectives of Multiple Stakeholders. She Ji: The Journal of Design, Economics, and Innovation, 3(3), 165-182.

Thimbleby, H. (2016). Human factors and missed solutions to Enigma design weaknesses. Cryptologia, 40(2), 177-202. https://doi.org/10.1080/01611194.2015.1028680

Thomas, J. C., \& Carroll, J. M. (1979). The psychological study of design. Design Studies, $1(1), 7-11$.

Toh, C. A., \& Miller, S. R. (2014). The impact of example modality and physical interactions on design creativity. Journal of Mechanical Design, 136(9), 091004.

Tracz, W. J. (1979). Computer programming and the human thought process. Software, practice and Experience, 9(2), 127-137. https://doi.org/10.1002/spe.4380090207

Tseng, I., Moss, J., Cagan, J., \& Kotovsky, K. (2008). The role of timing and analogical similarity in the stimulation of idea generation in design. Design Studies, 29(3), 203221. https://doi.org/10.1016/j.destud.2008.01.003 
Vanhove, A. J., \& Harms, P. D. (2015). Reconciling the Two Disciplines of Organisational Science: A Comparison of Findings from Lab and Field Research. Applied Psychology, 64(4), 637-673. https://doi.org/10.1111/apps.12046

Vasconcelos, L. A., \& Crilly, N. (2016). Inspiration and fixation: Questions, methods, findings, and challenges. Design Studies, 42, 1-32. https://doi.org/10.1016/i.destud.2015.11.001

Viswanathan, V., Atilola, O., Esposito, N., \& Linsey, J. (2014). A study on the role of physical models in the mitigation of design fixation. Journal of Engineering Design, 25(1-3), 2543.

Walsh, K. (2012). Board Editorial: Quantitative vs qualitative research: A false dichotomy. Journal of Research in Nursing, 17(1), 9-11. https://doi.org/10.1177/1744987111432053

Wilson, J. O., Rosen, D., Nelson, B. A., \& Yen, J. (2010). The effects of biological examples in idea generation. Design Studies, 31(2), 169-186. https://doi.org/10.1016/j.destud.2009.10.003

Wechsler, S. M., Vendramini, C. M. M., \& Oakland, T. (2012). Thinking and Creative Styles: A Validity Study. Creativity Research Journal, 24(2-3), 235-242. https://doi.org/10.1080/10400419.2012.677359

Weingart, S. B. (2015). Finding the History and Philosophy of Science. Erkenntnis, 80(1), 201-213. https://doi.org/10.1007/s10670-014-9621-1

Weick, K. (1979), The Social Psychology of Organizing. Reading, MA: Addison-Wesley.

Whitfield, P. R. (1975). Creativity in industry. Harmondsworth, UK, penguin.

Woodson, T. T. (1966). Introduction to engineering design. McGraw-Hill.

Wray, K. B. (2010). Philosophy of Science: What are the Key Journals in the Field? Erkenntnis, 72(3), 423-430.

Yilmaz, S., Seifert, C. M., \& Gonzalez, R. (2010). Cognitive heuristics in design: Instructional strategies to increase creativity in idea generation. Artificial Intelligence for Engineering Design, Analysis and Manufacturing, 24(03), 335-355. https://doi.org/10.1017/S0890060410000235

Yilmaz, Seda, \& Seifert, C. M. (2011). Creativity through design heuristics: A case study of expert product design. Design Studies, 32(4), 384-415. https://doi.org/10.1016/j.destud.2011.01.003

Youmans, R. J. (2011a). Design fixation in the wild: design environments and their influence on fixation. The Journal of Creative Behavior, 45(2), 101-107.

Youmans, R. J. (2011b). The effects of physical prototyping and group work on the reduction of design fixation. Design Studies, 32(2), 115-138.

Youmans, R. J., \& Arciszewski, T. (2014). Design fixation: Classifications and modern methods of prevention. Al EDAM, 28(Special Issue 02), 129-137.

https://doi.org/10.1017/S0890060414000043 
Zhang, H. Z., Xie, C., \& Nourian, S. (2017). Are their designs iterative or fixated? Investigating design patterns from student digital footprints in computer-aided design software. International Journal of Technology and Design Education, 24(02) 1-23. 


\section{Notes}

1 Jansson and Smith's (1991) Design Studies article titled 'Design Fixation' is commonly cited as the publication that coined that term. However, an earlier report on that work by the same authors, and with the same title, was presented at an NSF conference (Jansson \& Smith, 1989). A student of Jansson's had also submitted a thesis reporting similar work in 1988 titled 'Design fixation: an inhibition of creativity and quality in engineering design' (Mauldin, 1988). Gero's (1990) article on 'Design Prototypes' (and earlier variants) also referred to "design fixation, where the provision of a design description for a specified set of functions limits the designer's ability to produce structures other than those found in the design description" (p. 36). Interestingly, the term 'design fixation' was used much earlier with a similar but more general meaning in Garvin's (1964) essay on creativity in the architectural design process: "The flexibility of this [systematic] process contrasts sharply with the design fixation of the [rigid] Beaux Arts method" (p. 4). In a similar historical analysis, Brattinga (1964) states that early machine-made products exhibited a "fixation with historical forms [which] was a result of the inability of industry, and its architects and artists, to realize that the machine should produce forms designed originally for the machine's possibilities" (p. 6).

2 In adopting this general approach for illustrating the theoretical isolation of two streams of research, I drew inspiration from Wray's (2010) citation analysis and Weingart's (2015) network visualisation which they use to claim that despite institutional representations of 'History and Philosophy of Science' (e.g. centres, departments and journals with that name), it is not actually a field of study. They show that philosophy of science is more accurately a sub-field of philosophy and is disconnected from the history of science (for a discussion that this situation was already observed and discussed by Kuhn and others, see Wray, 2010, pp. 428, 429).

${ }^{3}$ In such fields, calls for pluralism aren't always calls for the introduction of quantitative methods however. Instead there are sometimes concerns about an overreliance on open-ended interview techniques rather than other qualitative approaches (e.g. see Dainty, 2009, p. 7; and for broader arguments see Janesick, 1998; Taylor \& Coffey, 2009). In this sense, arguments for methodological pluralism in design fixation could just as well be directed at the qualitative work as the experimental work.

${ }^{4}$ One of the disciplines that design fixation research can easily be compared to is ergonomics, especially cognitive ergonomics. This is because designing can be viewed as a human activity that is prone to 'errors' such as fixation. For an interesting example of how this might look, see Thimbleby's (2016) ergonomic analysis of the design of the Enigma machine, a design process which exhibited persistent failures to seek out more effective designs.

${ }^{5}$ In statistical analysis 'Type I' and 'Type II' errors are well defined and commonly understood: a Type I error (or 'error of the first kind') is the rejection of a true null hypothesis (a 'false positive'); a Type II error (or 'error of the second kind') is the failure of rejecting a false null hypothesis (a 'false negative'). In contrast, there are various different meanings of Type III errors (or 'errors of the third kind'). However, here Mackenzie and House are seemingly referring to something like Kimball's (1957) general description of the problem: "A simple and almost ludicrous definition of the error of the third kind is the error committed by giving the right answer to the wrong problem. [...] Many of us [statisticians], in good faith, have helped research workers make $t$-tests, or compute analyses of variance, or design experiments thinking we were giving the right answer to the right problem; and usually we do give the right answer to the question that is asked. Unfortunately it often happens that the question asked has little bearing on the real problem, and we are led into committing the third kind of error" (pp. 134-135). 